\title{
INFLUENCE OF PRE- AND POSTPARTUM SUPPLEMENTATION OF FIBROLYTIC ENZYMES AND YEAST CULTURE, OR BOTH, ON PERFORMANCE AND METABOLIC STATUS OF DAIRY COWS*
}

\author{
Magdalena Łopuszańska-Rusek, Krzysztof Bilik \\ Department of Animal Nutrition and Feed Science, National Research Institute of Animal Production, \\ 32-083 Balice n. Kraków, Poland
}

\begin{abstract}
The aim of the study was to determine the degree to which feeding total mixed rations (TMR) with fibrolytic enzymes and/or live yeast cultures to periparturient dairy cows will affect feed intake and conversion, milk yield and chemical composition, and metabolic and reproductive parameters of the cows. The experiment was conducted from 3 weeks before calving to 10 weeks of lactation on 36 Polish Red-and-White Holstein-Friesian (PHF Red) cows assigned to four analogous groups, 9 animals each. Cows from the control group (C) were fed an unsupplemented diet, those from group $\mathrm{E}$ received a diet supplemented $(15 \mathrm{~g} / \mathrm{day})$ with enzyme preparation $\left(\right.$ Fibrozyme $\left.^{\mathrm{TM}}\right)$ containing a blend of active xylanase and cellulase, cows from group $D$ a diet with yeast preparation (Yea - Sacc $\left.{ }^{1026}\right)$ supplemented (10 g/day) with Saccharomyces cerevisia $e^{1026}$ live yeast culture, and cows from group ED were fed a diet supplemented with a mixture $(25 \mathrm{~g} / \mathrm{day})$ of both feed additives. The preparations were added to the concentrate included in the TMR diet. It was found that groups $E$ and $D$ showed a tendency towards higher dry matter and nutrient intake compared to group C. In groups E, D and ED there was also a tendency towards higher milk yield (by about 4-12\% in the first 3 weeks of lactation) and slightly higher crude protein content (by an average of $0.16,0.09$ and 0.04 percentage units, respectively), without a clear effect on the other milk constituents. Significantly $(\mathbf{P}<\mathbf{0 . 0 5})$ lower milk urea content was also noted in group $\mathbf{E}$ compared to group $C$. Cows from groups $E$ and $D$ compared to group $C$, were characterized by better $(P<0.05)$ efficiency of feed and nutrient conversion for $\mathrm{kg}$ milk production, especially during the first three weeks after calving. The experimental cows also showed a tendency towards improved blood metabolic profile, especially decreased levels of beta-hydroxybutyric acid (BHBA) and reduced activity of aspartate aminotransferase (AST). The investigated preparations had no significant effect on the body weight, body condition and reproductive parameters of the cows.
\end{abstract}

Key words: dairy cows, fibrolytic enzymes, live yeast cultures, milk yield, blood metabolic profile, fertility indices

\footnotetext{
* Research project was conducted on the basis of PhD grant awarded by the Ministry of Science and Higher Education, project no. N311 067 32/3653.
} 
The high production potential of modern Holstein-Friesian (HF) dairy cows caused conventional feeding and housing systems to become less effective (Strzetelski et al., 2009). Animals of this breed require better housing and management conditions, but especially more accurate ration formulation in different stages of the production cycle (Osięgłowski and Strzetelski, 2006). The periparturient period is critically important to the feeding of dairy cows because it often involves disturbed fermentation processes in the rumen and an energy deficit (Stevenson, 2001; Strzetelski et al., 2008). Feeding rations high in starchy concentrates during this period with inadequate supply of structural feeds (roughages) may excessively lower the $\mathrm{pH}$ of ruminal fluid, lead to diseases and metabolic disorders, weaken reproductive function, reduce the proliferation of cellulolytic bacteria, and cause udder and cloven-hoof diseases (Nocek, 1997; Drackley, 1999). This results from the increased requirement of nutrients needed for fetal and placental development and milk synthesis after calving, which is paralleled by lower feed intake capacity (Ingvartsen and Andersen, 2000). An important role in reducing the incidences of these disorders, increasing the digestibility of structural carbohydrates and better meeting the energy requirement of dairy cows can be played by feed additives such as exogenous fibrolytic enzymes (Bowman et al., 2002; Nowak et al., 2003) or live yeast cultures (Schingoethe et al., 2004; Erasmus et al., 2005). In an age of increasing ecological awareness, their use in animal nutrition is not so objectionable as the use of synthetic feed additives (Beauchemin et al., 1999). Research on the feeding of exogenous fibrolytic enzymes in liquid form (aqueous solutions) to high-yielding HF dairy cows showed that they generally had beneficial effects on feed conversion and production results (Kung et al., 2002; Beauchemin et al., 2003; Sutton et al., 2003; Eun et al., 2007). Similar results were observed when diets were supplemented with live yeast cultures (Newbold et al., 1995; Strzetelski et al., 1996; Miller-Webster et al., 2002). There are no exhaustive studies available in animal science literature on the efficiency of adding fibrolytic enzymes as powdered preparation or enzyme and yeast composite to the concentrate in the total mixed ration (TMR) of dairy cows. It was also necessary to test the efficiency of using these feed additives in the nutrition of dairy cows because of the ongoing concentration of specialized dairy cattle farming in free-stall barns and the introduction of new feed evaluation and feed allocation systems for ruminants (Strzetelski, 1997).

The aim of the study was to determine whether feeding TMR diets with enzyme preparation and/or live yeast cultures to periparturient Polish Red-and-White Holstein-Friesian (PHF Red) cows will positively affect feed intake and conversion, milk yield, blood metabolite levels and reproductive parameters of the cows.

\section{Material and methods}

\section{Experimental design, animal feeding and housing}

The experiment involved 36 Polish Red-and-White Holstein-Friesian (PHF Red) cows from 3 weeks before calving to 10 weeks of lactation. The cows were studied 
in 2007-2008 at the Experimental Station of the National Research Institute of Animal Production, Grodziec Śląski Ltd. The experimental animals were selected from a herd of about 200 cows with an annual milk yield of 7000-8000 kg per cow. Cows were assigned to four analogous groups (with 9 animals per group) according to body weight, lactation number, percentage of HF genes, milk yield for the last 100day lactation and expected calving date. The average inheritance of HF genes in the feeding groups was $87.5 \%$ (67.5-97.5\%). The control group (C) was fed a complete (TMR) diet without supplements, group E received the identical ration with enzyme preparation (Fibrozyme ${ }^{\mathrm{TM}}, 15 \mathrm{~g} /$ day) containing a composite of active xylanase and cellulase, group D was supplemented with a yeast preparation (Yea - Sacc ${ }^{1026}$, $10 \mathrm{~g} /$ day) containing dried live yeast culture (Saccharomyces cerevisiae ${ }^{1026}$ ), and group ED was supplemented ( $25 \mathrm{~g}$ /day) with a mixture of both feed additives. Every day the preparations were added during the morning feeding to the concentrate included in the TMR diet, formulated according to IZ - INRA standards (2001) using INRAtion software (ver. 3.23; 2006). The composition of the TMR diet differed in the percentage of roughage and concentrate according to the study period (Table 1). Cows were fed individually twice daily and the amount of feed consumed was recorded. During the experiment, animals were kept in a barn for dry and freshly calved cows. Straw-bedded tie stalls were equipped with automatic drinkers, milking installation and trough partitions to allow for individual feeding.

Table 1. Daily rations for cows

\begin{tabular}{|c|c|c|c|c|}
\hline \multirow{5}{*}{ Feeds } & \multicolumn{4}{|c|}{ Experimental period } \\
\hline & \multicolumn{2}{|c|}{ dry period (last 3 weeks before calving) } & \multicolumn{2}{|c|}{ lactation ( 1 to 10 weeks) } \\
\hline & \multicolumn{4}{|c|}{ amount of feed (kg/day) } \\
\hline & \multicolumn{2}{|r|}{ TMR I } & \multicolumn{2}{|r|}{ TMR II } \\
\hline & $\mathrm{DM}$ & $\begin{array}{c}\text { proportion in TMR DM } \\
(\%)\end{array}$ & $\mathrm{DM}$ & $\begin{array}{c}\text { proportion in TMR DM } \\
(\%)\end{array}$ \\
\hline Maize silage & 3.5 & 26.76 & 6.8 & 32.12 \\
\hline Ensiled maize grain & 1.2 & 9.17 & 2.4 & 11.34 \\
\hline Wilted grass silage & 1.8 & 13.76 & 3.5 & 16.53 \\
\hline Barley straw & 2.1 & 16.05 & & \\
\hline Meadow hay & 0.5 & 3.82 & 0.3 & 1.42 \\
\hline Brewers' grains & 1.0 & 7.65 & 1.9 & 8.97 \\
\hline Concentrate* & 2.98 & 22.78 & 6.27 & 29.62 \\
\hline Total & 13.08 & 100.0 & 21.17 & 100.0 \\
\hline
\end{tabular}

*Concentrate diet contained (\%): ground wheat 27 , ground barley 18 , ground triticale 9 , soybean meal 18 , rapeseed meal 10, rapeseed expeller 10, ground limestone 4, mineral-vitamin premix 4.

\section{Measurements, chemical analyses and statistical calculations}

During the experiment, chemical composition and intake of feeds, cows' body weight and condition, milk yield and chemical composition, blood components and 
reproductive parameters were determined. All chemical analyses were performed at the Central Laboratory of the National Research Institute of Animal Production in Aleksandrowice, according to currents standards. Basic chemical composition of the feeds was determined using the standard procedure (AOAC, 1995), and ADF and NDF fibre fractions in roughages according to Goering and Van Soest (1970). The $\mathrm{pH}$ of silages was determined using an Elwro N 5170 potentiometer. Volatile fatty acid (VFA) analyses in silages were performed with gas chromatography (Varian 3400 , column CP-WAX 58, $25 \mathrm{~m}, 0.53 \mathrm{~mm}, 1.0$ micron, FID detection, $260^{\circ} \mathrm{C}$, range 11 , helium as carrier gas, $6 \mathrm{ml} / \mathrm{min}$, injector temperature $200^{\circ} \mathrm{C}$ ), using an $8200 \mathrm{CX}$ autosampler. Lactic acid in the silages was determined by high-performance liquid chromatography (HPLC) after centrifugation of water filtrates with $24 \%$ metaphosphoric acid using a Shimadzu chromatograph (column Nucleosil 250/4 - C18, detector UV-Vis SPP-6 AV and autosampler SIL-10 AX). Feed (TMR) intake by the cows was determined by weighing feed offered and feed refusals on 3 successive days during the third and last week before calving and in the first, fifth and tenth week after calving. Body weight and body condition score (BCS) on a 5-point scale were evaluated 7 days before expected parturition and at 7, 35 and 70 days after calving. Animals were weighed at the same time in the morning, prior to feeding. Body condition was estimated independently by 2 or 3 evaluators in accordance with DEFA recommendations (2001). The mean of individual scores served as the ultimate score. Milk yield was determined based on daily records of the amount of milk drawn from every cow using TRU-TEST milk meters. Chemical composition of milk (solids, crude protein, casein, fat, lactose, urea) was determined using a Milkoscan FT 120. Cows were milked twice daily in stalls. Milk samples were collected into 50-ml plastic containers (Chemix, Olsztyn), preserved with 2-bromo2-nitro-1,3-propanediol (GROPOL) and stored until analysis in a freezer $\left(-20^{\circ}\right)$ for about two weeks. Blood for analyses was collected from all animals 7 days before and 10 days after parturition. Tubes with whole blood were stored at room temperature for $1 \mathrm{~h}$, after which serum was extracted into $1.5 \mathrm{ml}$ Eppendorf tubes and frozen. After thawing, serum was analysed for free fatty acids (FFA), beta-hydroxybutyric acid (BHBA), glucose, urea, albumins and aspartate aminotransferase (AST). FFA and $\mathrm{BHBA}$ content was determined by the enzymatic-colorimetric method using a Cobas-Bio automatic analyser (ROCHE) at $37^{\circ} \mathrm{C}$ and a wavelength of $550 \mathrm{~nm}$ for FFA and $340 \mathrm{~nm}$ for BHBA. FFA were determined using standard reagents: WAKO Chemicals USA, WKT $\mathrm{C}$ test Kit and ACS-ACOD method, while BHBA was determined using RANDOX, RANBUT, Cobas MIRA and HANT-PROD Warsaw reagents. The level of glucose, urea, albumins and AST was determined by dry colorimetric technique using a KODAK analyser (VITROS 250 Chemistry). Fertility parameters of the cows were determined based on insemination index (services per conception), conception rate (pregnancy rate after first insemination) and calvingto-conception interval (days). The ease of parturition was scored on a 3-point scale (Pirlo et al., 1997): spontaneous (no assistance), intermediate (moderate assistance) and complicated (veterinary assistance). 


\section{Calculations and statistical analysis}

Statistical calculations were performed by one-factor analysis of variance using the ANOVA procedure of the SAS Enterprise Guide 4.1 (2006), and significance of differences between the groups was determined using Duncan's test.

\section{Results}

The nutrient content of roughages and concentrates and their nutritive value (Table 2) corresponded to parameters characterizing feeds of average quality. In particular periods of the experiment, daily feed (TMR) and nutrient intake by the cows were similar $(\mathrm{P}>0.05)$ in all the groups (Table 3$)$. However, cows from groups $\mathrm{E}$ and $\mathrm{D}$, especially during the first three weeks of lactation, showed a tendency towards slightly greater intake of dry matter (DM), energy (UFL) and protein (CP, PDIN and PDIE) compared to the control group (C).

Table 2. Chemical composition and nutritive value of the feeds

\begin{tabular}{|c|c|c|c|c|c|c|c|c|c|c|}
\hline \multirow[b]{2}{*}{ Feed } & \multirow{2}{*}{$\begin{array}{c}\text { Dry } \\
\text { matter } \\
(\%)\end{array}$} & \multicolumn{6}{|c|}{ Content in DM (\%) } & \multicolumn{3}{|c|}{ Content per $\mathrm{kg}$ feed DM } \\
\hline & & $\begin{array}{c}\text { crude } \\
\text { ash }\end{array}$ & $\begin{array}{c}\text { crude } \\
\text { protein }\end{array}$ & $\begin{array}{c}\text { ether } \\
\text { extract }\end{array}$ & $\begin{array}{l}\text { crude } \\
\text { fibre }\end{array}$ & $\mathrm{ADF}$ & NDF & UFL & $\begin{array}{c}\text { PDIN } \\
(\mathrm{g})\end{array}$ & $\begin{array}{l}\text { PDIE } \\
(\mathrm{g})\end{array}$ \\
\hline Maize silage & 29.20 & 4.48 & 8.59 & 3.97 & 19.83 & 29.90 & 41.61 & 0.83 & 52.00 & 65.00 \\
\hline Wilted grass silage & 37.50 & 11.00 & 12.15 & 3.92 & 29.36 & 38.24 & 53.12 & 0.72 & 73.00 & 61.00 \\
\hline Ensiled maize grain & 58.10 & 1.26 & 8.20 & 4.61 & 2.38 & 2.54 & 8.46 & 1.22 & 56.00 & 67.00 \\
\hline Meadow hay & 85.20 & 9.23 & 9.11 & 1.78 & 34.19 & 39.50 & 35.75 & 0.66 & 59.00 & 71.00 \\
\hline Barley straw & 87.70 & 5.16 & 4.46 & 2.06 & 44.34 & 54.16 & 80.35 & 0.42 & 22.00 & 44.00 \\
\hline Brewers' grains & 23.63 & 4.25 & 27.84 & 8.35 & 16.06 & & & 0.84 & 206.00 & 179.00 \\
\hline Wheat & 86.54 & 1.80 & 12.75 & 1.51 & 2.62 & & & 1.14 & 73.00 & 98.00 \\
\hline Soybean meal & 89.54 & 8.01 & 53.47 & 1.59 & 3.76 & & & 1.22 & 393.00 & 272.00 \\
\hline Rapeseed meal & 88.63 & 6.78 & 35.32 & 10.41 & 12.99 & & & 0.93 & 245.00 & 154.00 \\
\hline Rapeseed expeller & 89.30 & 6.84 & 34.96 & 10.60 & 13.41 & & & 1.07 & 227.00 & 147.00 \\
\hline Barley & 88.19 & 2.87 & 10.40 & 3.47 & 7.94 & & & 1.12 & 70.00 & 100.00 \\
\hline Triticale & 85.96 & 1.98 & 10.10 & 1.58 & 2.56 & & & 1.15 & 66.00 & 94.00 \\
\hline Concentrate & 88.24 & 5.23 & 16.42 & 1.34 & 3.13 & & & 1.09 & 156.00 & 131.00 \\
\hline TMR I (“dry period”) & 41.71 & 7.47 & 14.29 & 3.64 & 19.81 & 25.20 & 44.50 & 0.67 & 74.00 & 75.00 \\
\hline TMR II ("lactation") & 41.52 & 7.57 & 17.05 & 4.02 & 17.45 & 23.55 & 38.56 & 0.85 & 98.00 & 93.00 \\
\hline
\end{tabular}

Body weight and body condition of the cows before calving and in different lactation periods did not differ significantly $(\mathrm{P}>0.05)$ between the groups (Table 4$)$. Compared to 7 days before calving, average body weight of the cows at 7, 30 and 70 days after calving was lower by about $10 \%, 15 \%$ and $13 \%$, respectively. A similar tendency was also found for body condition score (BCS), which was about $0.57,0.65$ 
and 0.55 points lower at 7, 30 and 70 days after calving, respectively, compared to 7 days before calving.

Table 3. Mean daily intake of feed and nutrients

\begin{tabular}{|c|c|c|c|c|c|c|}
\hline \multirow{2}{*}{ Item } & \multicolumn{4}{|c|}{ Groups } & \multirow{2}{*}{ SEM } & \multirow{2}{*}{$\mathrm{P}$} \\
\hline & $\mathrm{C}$ & $\mathrm{E}$ & $\mathrm{D}$ & ED & & \\
\hline \multicolumn{7}{|c|}{ Before calving (21-1 days): } \\
\hline TMR (kg) & 32.6 & 33.7 & 35.14 & 32.7 & 3.24 & 0.07 \\
\hline Dry matter - DM (kg) & 13.6 & 14.1 & 14.7 & 13.6 & 1.26 & 0.07 \\
\hline Crude protein $-\mathrm{CP}(\mathrm{g})$ & 1943.4 & 2014.9 & 2100.6 & 1943.4 & 170.8 & 0.07 \\
\hline PDIN (g) & 1006.4 & 1043.4 & 1087.8 & 1006.4 & 103.9 & 0.07 \\
\hline PDIE (g) & 1020.0 & 1057.5 & 1102.5 & 1020.0 & 99.6 & 0.07 \\
\hline UFL & 9.1 & 9.5 & 9.9 & 9.1 & 0.8 & 0.07 \\
\hline \multicolumn{7}{|l|}{ After calving (days): } \\
\hline \multicolumn{7}{|l|}{ 1-21: } \\
\hline TMR (kg) & 50.7 & 52.6 & 51.6 & 49.64 & 2.70 & 0.15 \\
\hline $\mathrm{DM}(\mathrm{kg})$ & 21.0 & 21.8 & 21.4 & 20.6 & 1.13 & 0.15 \\
\hline $\mathrm{CP}(\mathrm{g})$ & 3580.5 & 3716.9 & 3648.7 & 3512.3 & 163.04 & 0.15 \\
\hline PDIN (g) & 2058.0 & 2136.4 & 2097.2 & 2018.8 & 108.80 & 0.15 \\
\hline PDIE (g) & 1953.0 & 2027.4 & 1990.2 & 1915.8 & 103.26 & 0.15 \\
\hline UFL & 17.9 & 18.5 & 18.2 & 17.5 & 0.92 & 0.15 \\
\hline \multicolumn{7}{|l|}{$22-70:$} \\
\hline TMR (kg) & 52.8 & 53.2 & 52.8 & 52.2 & 1.06 & 0.19 \\
\hline $\mathrm{DM}(\mathrm{kg})$ & 21.9 & 22.1 & 21.9 & 21.7 & 1.66 & 0.17 \\
\hline $\mathrm{CP}(\mathrm{g})$ & 3733.9 & 3768.1 & 3733.9 & 3699.9 & 163.23 & 0.17 \\
\hline PDIN (g) & 2146.2 & 2165.8 & 2146.2 & 2126.6 & 102.37 & 0.17 \\
\hline PDIE (g) & 2036.7 & 2055.3 & 2036.7 & 2018.1 & 98.51 & 0.17 \\
\hline UFL & 18.6 & 18.8 & 18.6 & 18.4 & 0.65 & 0.17 \\
\hline \multicolumn{7}{|l|}{ 1-70: } \\
\hline TMR (kg) & 51.7 & 52.9 & 52.2 & 50.9 & 2.58 & 0.27 \\
\hline DM (kg) & 21.5 & 21.9 & 21.7 & 21.1 & 1.06 & 0.26 \\
\hline $\mathrm{CP}(\mathrm{g})$ & 3665.8 & 3733.9 & 3699.9 & 3597.6 & 155.85 & 0.27 \\
\hline PDIN (g) & 2107.0 & 2146.2 & 2126.6 & 2067.8 & 103.98 & 0.27 \\
\hline PDIE (g) & 1999.5 & 2036.7 & 2018.1 & 1962.3 & 98.68 & 0.27 \\
\hline UFL & 18.3 & 18.6 & 18.4 & 17.9 & 0.88 & 0.27 \\
\hline
\end{tabular}

No significant $(\mathrm{P}>0.05)$ differences were found between the groups in the milk yield of cows during the 10-week lactation period (Table 4). However, a tendency for higher daily milk yield was noted in groups E, D and ED in the first three weeks of lactation (by an average of 11, 12 and 5\%, respectively). A tendency for higher milk protein (by about 0.16 and 0.09 percentage units) and casein (by about 0.15 and 0.07 percentage units, respectively) was found. The milk of group E cows was also characterized by lower $(\mathrm{P}<0.05)$ urea content compared to other groups. In the first 3 weeks of lactation, cows from groups $\mathrm{E}$ and $\mathrm{D}$ were characterized by a significantly lower $(\mathrm{P}<0.05)$ feed $(\mathrm{TMR})$ and nutrient (crude protein, PDI and UFL) intake for $\mathrm{kg}$ milk production compared to the control group (Table 4). A similar tendency was also observed in the other lactation periods (22-70 and 1-70 days), but the differences were not significant $(\mathrm{P}>0.05)$. 
Table 4. Cows' body weight and body condition score, milk yield and chemical composition, and feed conversion per kg milk

\begin{tabular}{|c|c|c|c|c|c|c|}
\hline \multirow{2}{*}{ Items } & \multicolumn{4}{|c|}{ Groups } & \multirow{2}{*}{ SEM } & \multirow{2}{*}{$\mathrm{P}$} \\
\hline & $\mathrm{C}$ & E & D & ED & & \\
\hline \multicolumn{7}{|l|}{ Body weight (kg): } \\
\hline $\begin{array}{l}\text { before calving (day 7) } \\
\text { after calving (davs): }\end{array}$ & 691.2 & 687.2 & 689.3 & 687.2 & 37.5 & 0.99 \\
\hline 7 & 623.3 & 615.2 & 620.4 & 621.5 & 78.6 & 0.65 \\
\hline 30 & 585.0 & 581.2 & 584.2 & 581.4 & 28.9 & 0.93 \\
\hline 70 & 594.2 & 595.3 & 599.3 & 600.2 & 27.56 & 0.85 \\
\hline \multicolumn{7}{|l|}{$\begin{array}{l}\text { Body condition score } \\
\text { (BCS, pts): }\end{array}$} \\
\hline $\begin{array}{l}\text { before calving (day 7) } \\
\text { after calving (days): }\end{array}$ & 3.46 & 3.48 & 3.51 & 3.49 & 0.15 & 0.98 \\
\hline 7 & 2.99 & 3.01 & 2.98 & 2.99 & 0.21 & 0.37 \\
\hline 30 & 2.97 & 2.99 & 2.95 & 2.98 & 0.18 & 0.48 \\
\hline 70 & 3.00 & 3.05 & 3.00 & 3.05 & 0.17 & 0.86 \\
\hline \multicolumn{7}{|l|}{ Milk yield (kg): } \\
\hline $\begin{array}{l}\text { total from } 1 \text { to } 70 \text { days } \\
\text { daily by period (days): }\end{array}$ & 2033.3 & 2181.2 & 2170.63 & 2115.51 & 295.1 & 0.7 \\
\hline $1-21$ & 26.0 & 29.6 & 30.0 & 27.3 & 4.25 & 0.23 \\
\hline $22-70$ & 30.3 & 31.8 & 31.4 & 31.3 & 4.05 & 0.95 \\
\hline $1-70$ & 29.0 & 31.2 & 31.0 & 30.2 & 4.11 & 0.77 \\
\hline \multicolumn{7}{|l|}{ Milk composition (\%): } \\
\hline solids & 12.07 & 12.36 & 12.55 & 12.06 & 0.99 & 0.7 \\
\hline fat & 3.91 & 3.93 & 3.85 & 3.89 & 0.28 & 0.9 \\
\hline protein & 3.28 & 3.44 & 3.37 & 3.32 & 0.17 & 0.2 \\
\hline casein & 2.67 & 2.82 & 2.74 & 2.51 & 0.33 & 0.2 \\
\hline lactose & 4.80 & 4.78 & 4.82 & 4.77 & 0.11 & 0.8 \\
\hline urea $(\mathrm{mg} / \mathrm{l})$ & $208.9 \mathrm{a}$ & $172.1 \mathrm{~b}$ & $202.33 \mathrm{ab}$ & $213.56 \mathrm{a}$ & 38.51 & 0.05 \\
\hline
\end{tabular}

Feed conversion per kg milk by period (days):

$$
1-21:
$$

TMR $(\mathrm{kg})$
DM $(\mathrm{kg})$
CP $(\mathrm{g})$
PDI $(\mathrm{g})$
UFL

22-70:

TMR $(\mathrm{kg})$

$\mathrm{DM}(\mathrm{kg})$

$\mathrm{CP}(\mathrm{g})$

PDI $(g)$

UFL

$\begin{array}{cc}1.95 \mathrm{a} & 1.78 \mathrm{~b} \\ 0.81 \mathrm{a} & 0.74 \mathrm{~b} \\ 137.7 \mathrm{a} & 125.6 \mathrm{~b} \\ 75.1 \mathrm{a} & 68.5 \mathrm{~b} \\ 0.68 \mathrm{a} & 0.63 \mathrm{~b}\end{array}$

$$
1.74
$$

0.72

123.2

67.2

0.61

1.67
0.69
118.5
64.6
0.59

0.59
$1.72 \mathrm{~b}$

$0.71 \mathrm{~b}$

$121.6 \mathrm{~b}$

$66.3 \mathrm{~b}$

$0.61 \mathrm{~b}$
$1.82 \mathrm{ab}$

$0.76 \mathrm{ab}$ $128.7 \mathrm{ab}$

$70.18 \mathrm{ab}$

$0.65 \mathrm{ab}$
0.10

0.04

6.93

3.78

0.03

0.06

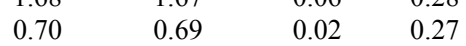

$\begin{array}{llll}118.9 & 118.2 & 12.7 & 0.27\end{array}$

$\begin{array}{llll}64.9 & 64.5 & 7.5 & 0.26\end{array}$

$\begin{array}{llll}0.59 & 0.59 & 0.06 & 0.27\end{array}$

1-70:

\begin{tabular}{lcccccc} 
TMR $(\mathrm{kg})$ & 1.79 & 1.70 & 1.69 & 1.69 & 0.10 & 0.32 \\
DM $(\mathrm{kg})$ & 0.75 & 0.71 & 0.70 & 0.70 & 0.04 & 0.36 \\
CP $(\mathrm{g})$ & 126.4 & 119.7 & 119.4 & 119.1 & 6.44 & 0.31 \\
PDI $(\mathrm{g})$ & 69 & 65.3 & 65.1 & 65.0 & 3.52 & 0.32 \\
UFL & 0.64 & 0.60 & 0.6 & 0.6 & 0.03 & 0.36 \\
\hline
\end{tabular}

$\mathrm{a}, \mathrm{b}-\mathrm{P}<0.05$. 
The values of some biochemical parameters of blood are given in Table 5. The blood serum collected 7 days before calving from cows from groups E, D and ED was characterized by a significantly lower $(\mathrm{P}<0.05)$ level of the liver enzyme (AST) compared to group $\mathrm{C}$ as well as no significant $(\mathrm{P}>0.05)$ differences in the other serum parameters (FFA, BHBA, glucose, urea and albumins). Seven days after calving no significant differences were found between the groups in the blood metabolite levels.

Table 5. Blood biochemical components

\begin{tabular}{l|c|c|c|c|c|c}
\hline \multirow{2}{*}{ Item } & \multicolumn{7}{c|}{ Groups } & \multirow{2}{*}{ SEM } & P \\
\cline { 2 - 4 } & $\mathrm{C}$ & $\mathrm{E}$ & $\mathrm{D}$ & $\mathrm{ED}$ & & \\
\hline Before calving (day 7): & & & & & \\
FFA (mml/l) & 0.36 & 0.35 & 0.31 & 0.38 & 0.28 & 0.96 \\
BHBA (mml/l) & 0.61 & 0.49 & 0.53 & 0.52 & 0.14 & 0.71 \\
Glucose (mml/l) & 3.70 & 3.75 & 3.87 & 3.78 & 0.73 & 0.96 \\
Urea (mml/l) & 3.24 & 3.78 & 3.44 & 3.38 & 0.97 & 0.68 \\
Albumins (g/l) & 31.0 & 30.0 & 29.0 & 28.0 & 2.53 & 0.06 \\
AST (U/l) & $98.0 \mathrm{a}$ & $69.0 \mathrm{~b}$ & $70.0 \mathrm{~b}$ & $74.0 \mathrm{~b}$ & 22.85 & 0.04 \\
After calving (day 7): & & & & & \\
FFA (mml/l) & 0.74 & 0.54 & 0.73 & 0.72 & 0.42 & 0.71 \\
BHBA (mml/l) & 1.37 & 0.88 & 0.85 & 1.18 & 0.66 & 0.71 \\
Glucose (mml/l) & 3.59 & 3.07 & 3.06 & 3.19 & 0.65 & 0.28 \\
Urea (mml/l) & 3.60 & 3.21 & 2.98 & 3.40 & 1.28 & 0.76 \\
Albumins (g/l) & 30.0 & 30.0 & 29.8 & 29.7 & 2.53 & 0.06 \\
AST (U/l) & 124.0 & 96.0 & 102.0 & 123.0 & 43.20 & 0.41 \\
\hline
\end{tabular}

$\mathrm{a}, \mathrm{b}-\mathrm{P}<0.05 ; \mathrm{A}, \mathrm{B}-\mathrm{P}<0.01$.

Table 6. Fertility indices of the cows

\begin{tabular}{|c|c|c|c|c|c|c|}
\hline \multirow{2}{*}{ Item } & \multicolumn{4}{|c|}{ Groups } & \multirow{2}{*}{ SEM } & \multirow{2}{*}{$\mathrm{P}$} \\
\hline & $\mathrm{C}$ & $\mathrm{E}$ & $\mathrm{D}$ & ED & & \\
\hline Insemination index & 2.44 & 2.22 & 2.33 & 2.33 & 1.37 & 0.73 \\
\hline Conception rate $(\%)$ & 22.2 & 44.4 & 44.4 & 44.4 & & \\
\hline Calving-to-conception interval (days) & 141.0 & 131.1 & 135.3 & 139.3 & 19.87 & 0.31 \\
\hline \multicolumn{7}{|l|}{ Course of calving ${ }^{1}$ (no. of cows): } \\
\hline $\mathrm{S}$ & 7 & 7 & 8 & 7 & & \\
\hline I & 2 & 1 & & 1 & & \\
\hline $\mathrm{C}$ & 0 & 1 & 1 & 1 & & \\
\hline
\end{tabular}

${ }^{1}$ According to a 3-point scale: $\mathrm{S}$ - spontaneous (no assistance); I - intermediate (moderate assistance); $\mathrm{C}$ - complicated (veterinary assistance).

In the herd of experimental cows, no significant $(\mathrm{P}>0.05)$ differences were observed in fertility parameters (Table 6). All of the cows on the experiment conceived after an average of 2.3 (1-4) inseminations. However, cows from groups E, D and ED demonstrated a higher pregnancy rate after first insemination and needed fewer inseminations to conceive compared to the control group (C). Groups E and D were 
also characterized by shorter calving-to-conception interval (by an average of 10 and 6 days, respectively) compared to animals from group C. Most parturitions were normal and only a very small number of animals needed veterinary assistance at calving.

\section{Discussion}

The intake and conversion of feed given to dairy cows from 3 weeks before calving to 70 days of lactation indicates that the feed additives did not significantly increase the dry matter and nutrient intake compared to the control group. Likewise, other authors (Robinson and Garrett, 1999; Dann et al., 2000; Wang et al., 2001) observed no significant effect of adding yeast and enzyme preparations to dairy cow diets during the precalving period on increased feed intake. The fact that the feed additives had no clear effect on feed intake by the cows suggests that feed intake during the precalving period may be largely regulated by non-feeding factors, especially the animal's metabolism and hormones (Robinson and Garrett, 1999; Morrison et al., 2001). Like in the precalving period, in the initial period of lactation our study and those of other authors (Lewis et al., 1999; Wang et al., 2001; Bowman et al., 2002) did not show a significant effect of supplementing enzyme and yeast preparations on feed and nutrient intake by the cows.

Maintaining the optimum condition and body weight of periparturient cows determines trouble-free transition from late pregnancy to early lactation (Mulligan et al., 2006). The body condition scores of cows in the last week before calving (3.5 pts) were close to the upper limit of normal BCS values (3.0-3.5 pts) specified by Contreras et al. (2004) for high-yielding Holstein-Friesian cows entering the dry period. Body condition scores for dry cows, recommended by the above authors, should result mainly from the development of fetal membranes as well as fetal and udder growth, and not from the deposition of body fat reserves. Other authors (Domecq et al., 1997) suggest that precalving cows should exhibit body condition scores of 3.2-3.7 pts, which in early lactation cows should not decrease by more than 0.5 pts compared to the precalving period. Like in other studies (Yang et al., 1999; Dann et al., 2000; Kung et al., 2002; Wang et al., 2001; Vicini et al., 2003; Erasmus et al., 2005), we did not observe a significant effect of using enzyme and/or yeast preparations during the periparturient and early lactation periods on the cows' body weight and body condition. The pre- and postcalving body weights ( $688 \mathrm{~kg}$ and $620 \mathrm{~kg}$ on average, respectively) obtained in our study are similar to Polish standards for dairy cows (Strzetelski et al., 1997), which may indicate that the feeding rations enabled the genetically determined production potential of the experimental animals to be optimally used (Bilik and Strzetelski, 2005).

The level of feeding in different periods of the production cycle affects the metabolic status of the cows, and the yield and chemical composition of their milk (Borkowska et al., 2006). The milk yield values obtained for cows supplemented with fibrolytic enzymes or yeast cultures confirm, to a certain degree, the findings of other authors (Strzetelski et al., 1996; Yang et al., 1999; Beauchemin et 
al., 2000; Sutton et al., 2003; Erasmus et al., 2005), who reported that their use in precalving and early lactation cows has a beneficial effect on their milk productivity. A tendency (especially in the first 3 weeks of lactation) for the higher milk yield of cows from groups receiving enzyme and/or yeast preparation could result from the increased amount of nutrients necessary for synthesis of milk in the udder, which originated from the increased ruminal nutrient degradation and better total tract nutrient digestion (Bowman et al., 2002; Nowak et al., 2003). Probably, this has also contributed to better and more efficient conversion of feed to production during the milk production period, without the need to mobilize the body's fat stores (Kung et al., 2000). The productivity of cows fed diets supplemented with fibrolytic enzymes is also affected to a large extent by the amount of enzyme preparation used (Yang et al., 1999) and the enzyme ratio in the enzyme complex (Kung et al., 2000). These authors suggest that excessive amounts of this dietary supplement may block the enzyme and substrate binding site and hinder rumen bacteria, or release antinutritional factors that reduce the microbiological digestibility of the feed. Some authors (Sutton et al., 2003) indicate that adding an aqueous solution of enzyme supplement to roughage directly before feeding produced better results than when used during ensiling or when given directly in the rumen in the form of an aqueous solution. The favourable production results of $\mathrm{HF}$ cows given an aqueous solution of fibrolytic enzymes at 1.25 or 2.0 litres per ton of complete diet (TMR) was not confirmed by Vicini et al. (2003). Some studies (Dann et al., 2000; Wang et al., 2001) also showed that precalving cows receiving a Saccharomyces cerevisiae ${ }^{1026}$ yeast preparation had higher milk yields and were quicker to achieve maximum production when entering lactation, which was also observed in our study. However, Wohlt et al. (1998) did not confirm the beneficial effect of using a yeast preparation on the milk yield of mid and late lactation cows, nor when using increased preparation doses on production parameters. It has been stressed (Dann et al., 2000; Mwenya et al., 2005) that the feeding efficiency of live yeast culture is visible especially in dairy herds characterized by a high production potential (over 301 of milk per day), and to a much lesser degree when feeding lower yielding cows.

Like our 10-week lactation study, other experiments (Sutton et al., 2003) failed to observe a significant effect of adding fibrolytic enzymes and/or live yeast cultures to complete diets (TMR) in the periparturient period on improving nutrient conversion. The tendency towards better nutrient conversion per $\mathrm{kg}$ milk in cows from groups $\mathrm{E}$ and D compared to the control cows (C), shown during the first three weeks of lactation, was mainly due to the higher milk yield of the cows from these groups, which is supported by the findings of other authors (Yang et al., 1999; Bowman et al., 2002).

Although the effect of adding fibrolytic enzymes and live yeast cultures on the percentage of milk ingredients is not conclusive, most researchers (Robinson, 1999; Soder and Holden, 1999; Yang et al., 1999; Beauchemin et al., 2000; Dann et al., 2000) observed that milk protein content tended to increase without a clear effect on the content of fat and other ingredients. This tendency is also confirmed by our study, which showed that feeding an enzyme or yeast additive to early lactation cows increases the milk protein and casein content and reduces the urea level while having 
no effect on fat and lactose content. This can be attributed to changes in the rumen fermentation processes under the influence of these additives, as reflected among others by lower urea concentration in the milk of cows after calving. This is indicative of the more efficient synthesis of microbial protein, the lower strain on the liver caused by ammonia detoxication, and the lower energy losses (Nowak et al., 2003). Our findings on the yield and chemical composition of milk from cows receiving the enzyme and yeast composite are confirmed by Soder and Holden (1999), who reported that giving a mixture of Biomate Yeast Plus ${ }^{\circledR}$ (containing Saccharomyces cerevisiae yeast cultures) and a complex of enzymes (amylase, protease and lipase) to cows in early lactation has no significant effect on the yield and content of basic milk ingredients.

Three serum parameters necessary to assess the cow's energy condition were used: glucose, free fatty acids (FFA) and beta-hydroxybutyric acid (BHBA). The physiologically normal serum FFA, glucose and BHBA levels observed in the cows 7 days before and after calving with close to optimum body condition may be evidence that the cows' energy requirement has been met and they have been properly prepared for lactation (Strzetelski et al., 2008). The lower serum levels of BHBA (although not confirmed statistically) and AST, found in the experimental groups before and after calving are evidence of the lower energy deficit of the cows supplemented with fibrolytic enzymes and/or yeast cultures. The serum urea levels found in our study show that the supply of ruminally degraded protein was appropriate (Chládek, 2002; Kowalski and Kamiński, 2000), as was liver function and supply of amino acids in the diet (Herdt, 2000; Reader, 2003). This is confirmed by the lower AST values found in the blood serum of cows from the experimental groups (E, D and ED) prior to calving, which also tended to remain lower after calving.

The results obtained in our study for the course of parturition are similar to those reported in the animal science literature (Pirlo et al., 1997; Bilik et al., 2004), which showed that the parturitions were mostly spontaneous or required moderate assistance. Also the other analysed reproductive parameters (insemination index, conception rate and calving-to-conception interval) were within the range considered normal for the cows of the breed studied. The lower conception rate in cows from the control group (C) could possibly be attributed to the higher urea-N content of milk from the cows, because Butler et al. (1996) demonstrated a negative relationship between milk urea level and cow fertility. It is also possible that several other environmental factors (related to oestrus detection, insemination technique and semen quality) could affect reproductive parameters of the cows (Stevenson, 2001). The decreased body condition of the cows, observed in our study from 7 to 70 days of lactation, was within the normal range and probably had no effect on the number of inseminations needed to obtain pregnancy. Also our results concerning the calving-to-conception interval (131-141 days) are similar to the values obtained in the pedigree herds of the cows of this breed.

In conclusion, the addition of fibrolytic enzymes or live yeast cultures to the TMR diets of periparturient dairy cows of the Polish Red-and-White Holstein-Friesian breed (from 3 weeks before calving to 10 weeks of lactation) tends to increase milk production by $7 \%$ (and by as much as $11 \%$ in the first three weeks of lactation) 
and improve DM, protein (PDI) and energy (UFL) conversion per milk in early lactation (1-21 days). The use of both additives at the same time (enzymatic-yeast mixture) has no effect on milk yield and content of basic milk components. The lower serum level of BHBA and lower AST in postparturient cows receiving fibrolytic enzymes and yeast cultures indicates their beneficial effect on the energy balance of the cows during the late dry period and the early lactation period. The use of the enzyme and/or yeast preparations in the periparturient and early lactation periods has no effect on changes in body weight and body condition or reproductive parameters of the cows. The possible introduction of feed additives containing fibrolytic enzymes and live yeast cultures into agricultural practice on Polish Holstein-Friesian cattle farms will depend on the cost of their manufacture, ease of application and efficiency under production conditions, but this requires further research.

\section{References}

B e a uchemin K.A., Colombato D., Morgavi D.P., Yang W.Z. (2003). Use of exogenous fibrolytic enzymes to improve feed utilization by ruminants. J. Anim. Sci., 81 (E. Suppl. 2): E37-E47.

B e a u ch e min K.A., R o d e L.M., M a k a w a M., Morgavi D.P., K a m pen R. (2000). Evaluation of a nonstarch polysaccharidase feed enzyme in dairy cow diets. J. Dairy Sci., 83: 543-553.

B e a u c h e m in K.A., Y an g W.Z., R o d e L.M. (1999). Effect of grain source and enzyme additive on site and extent of nutrient digestion in dairy cows. J. Dairy Sci., 8: 378-390.

Bilik K., Strzetelski J., Choroszy Z. (2004). Effect of feeding level in pubertal Red-andWhite $\times$ Holstein-Friesian heifers on some productive traits and later milk yield. Ann. Anim. Sci., 4: 371-386.

B i l i k K., S tr z e t e ls k i J. (2005). Milk yield pattern in primiparous cows of different breeds fed according to IZ-INRA requirements depending on body weight before first calving. (In Polish). Rocz. Nauk. Zoot., 32: 81-95.

B orkow ska D., J a n u ś E., M a lin ow sk a K. (2006). Urea Level in Milk of Cows fed Mainly on Feeds from Permanent Grassland. (In Polish). Annal. Zoot., S. EE, 24: 61-66.

B o w m a n G.R., B e a u c h e m in K.A., S h e l ford J.A. (2002). The proportion of the diet to which fibrolytic enzymes are added affects nutrient digestion by lactating dairy cows. J. Dairy Sci., 85: 3420-3429.

B u t l e r W.R., C l a m a n J.J., B e a m S.W. (1996). Plasma and milk urea nitrogen in relation to pregnancy rate in lactating dairy cattle. J. Anim. Sci., 74: 858-865.

C h l a d e k G. (2002). Blood plasma urea and its relationship with yield and composition of cow's milk. (In Polish). Med. Wet., 58: 871-872.

C ontreras L.L., R y a n C.M., Overto n T.R. (2004). Effect of dry cow grouping strategy and prepartum body condition score on performance and health of transition dairy cows. J. Dairy Sci., 87: 517-523.

Dann H.M., Drackley J.K., Mc Coy G.C., Hutjens M.F., Garrett J.E. (2000). Effects of yeast culture (Saccharomyces cerevisiae) on prepartum intake and postpartum intake and milk production of Jersey cows. J. Dairy Sci., 83:123-27.

D o m e c q J.J., S k i d m o r e A.L., L l o y d J.W., K a n e e n e J.B. (1997). Relationship between body condition scores and conception at first artificial insemination in a large dairy herd of high yielding Holstein cows. J. Dairy Sci., 80: 113-20.

D r a c k le y J.K. (1999). Biology of dairy cows during the transition period: the final frontier. J. Dairy Sci., 82: 2259-2273.

Eras mus L.J., Robinson P.H., Ahmadi A., Hinders R., Garrett J.E. (2005). Influence of prepartum and postpartum supplementation of a yeast culture and monensin, or both, on 
ruminal fermentation and performance of multiparous dairy cows. Anim. Feed Sci. Technol., 122: $219-239$.

Eun J.S., B e a u chemin K.A., S chulze H. (2007). Use of exogenous fibrolytic enzymes to enhance in vitro fermentation of alfalfa hay and corn silage. J. Dairy Sci., 90: 1440-1451.

He r d t T.H. (2000). Variability characteristics and test selection in herd-level nutritional and metabolic profile testing. Vet. Clin. North Am. Food Anim. Pract., 16: 387-403.

In g v a r t s e n K.L., A n d e r s e n J.B. (2000). Integration of metabolism and intake regulation: a review focusing on periparturient animals. J. Dairy Sci., 83: 1573-1597.

K o w a ls k i Z.M., K a m i ńs ki J. (2000). Some aspects of the nutrition of high yielding dairy cows. (In Polish). Post. Nauk Roln., 4: 77-98.

Kung L., Jr, T re a ch er R.J., N a u G.A., S m a g a la A.M., En d res K.M., Coh e n M.A. (2000). The effect of treating forages with fibrolytic enzymes on its nutritive value and lactation performance of dairy cows. J. Dairy Sci., 83: 115-122.

Kung L., Jr, Cohen M.A., Rode L.M., Treacher R.J. (2002). The effect of fibrolytic enzymes sprayed onto forages and fed in a total mixed ratio to lactating dairy cows. J. Dairy Sci., 85: 2396-2402.

Lew is G.E., Sanchez W.K., Hunt C.W., Guy M.A., Pritchard G.T., Swans on B.I., T r e a c h e r R.J. (1999). Effect of direct-fed fibrolytic enzymes on the lactational performance of dairy cows. J. Dairy Sci., 82: 611-617.

Mille r - W e b st e r T., H o over W.H., Holt M., N o c e k J.E. (2002). Influence of yeast culture on ruminal microbial metabolism in continuous culture. J. Dairy Sci., 85: 2009-2014.

Morrison C.D., Daniel J.A., Holmberg B.J., Dijane J. Raver N., Rertler A., K e is le r D.H. (2001). Central infusion of leptin into well-fed and undernourished ewe lambs: effect on feed intake and serum concentrations of growth hormone and luteinizing hormone. J. Endocrinol., 168: 317-324.

Mulligan F.J., O'Grady L., Rice D.A., Doherty M.L. (2006). A herd health approach to dairy cow nutrition and production diseases of the transition cow. Anim. Reprod. Sci., 96: $331-353$.

Mwenya B., Santoso B., Sar C., Pen B., Morikawa R., Takaura K., Umetsu K., Kimura K., Takahashi J. (2005). Effect of yeast culture and galacto-oligosaccharides on ruminal fermentation in Holstein cows. J. Dairy Sci., 88: 1404-1412.

Newbold C.J., W a 11 a c e R.J., Chen X.B., Mc In t o s h F.M. (1995). Different strains of Saccharomyces cerevisiae differ in their effects on ruminal bacterial numbers in vitro and in sheep. J. Anim. Sci., 73: 1811-1818.

N o c e k J.E. (1997). Bovine acidosis: Implications on laminitis. J. Dairy Sci., 80: 1005-1028.

Nowak W., Kruczyńs ka H., Grochows ka S. (2003). The effect of fibrolytic enzymes on dry matter, ADF and NDF ruminal disappearance and intestinal digestibility. Czech J. Anim. Sci., 48: 191-196.

Os i ęgłowski S., Strzetelski J. (2006). Effect of the period of feeding higher energy diets to prepartum cows on early-lactation milk yield. Pol. J. Nat. Sci., Suppl., 3: 211-217.

P ir lo G., Capellett i M., M a r h e t to G. (1997). Effects of energy and protein allowances in the diets of prepubertal heifers on growth and milk production. J. Dairy Sci., 80: 730-739.

R e a d e r J. (2003). Blood profiling bonus. Dairy Farmer Nutr., 3: 70-72.

R o b in s o n P.H., G a r r e t t J.E. (1999). Effect of yeast culture (Saccharomyces cerevisiae) on adaptation of cows to postpartum diets and on lactational performance. J. Anim Sci., 77: 988-999.

S ching o e the D.J., Linke K.N., K a l s che u r K.F., Hippen A.R., Rennich D.R., Yoon I. (2004). Feed efficiency of mid-lactation dairy cows fed yeast culture during summer. J. Dairy Sci., 87: 4178-4181.

S o d e r K.J., Holde n L.A. (1999). Dry matter intake and milk yield and composition of cows fed yeast prepartum and postpartum. J. Dairy Sci., 82: 605-610.

Stevens on J.S. (2001). Reproductive management of dairy cows in high milk producing herds. J. Dairy Sci.. 84 (E. Suppl.): E128-E143.

Strzetelski J. (1997). Effect of rations balanced according to new principles on performance of homeland dairy cows of different genotype. (In Polish). Rocz. Nauk. Zoot., Rozpr. hab., pp. 5-68. 
Strzetelski J., Kow a lczyk J., Bilik K., S tas iniewicz T., S oroka M., Niwińska B. (1996). Yeast cells as a feed supplement for cattle. 3. New yeast preparations for cows in the first period of lactation. J. Anim. Feed Sci., 5: 1-9.

Strzetelski J.A., Kowalski Z.M., Kowalczyk J., Borowiec F., Osięgłowski S., Śl u s a r c zy k K. (2009). Protected methionine as a methyl-group donor for dairy cows fed diets with different starch sources in the transition period. J. Anim. Feed Sci., 18: 28-41.

Strzetelski J.A., Os i ęgłowski S., Kowalski Z.M., Kowalczyk J., Borowiec F., S o s in E. (2008). Effect of pre- and-post-calving concentrate allocation and of starch source on feed intake, blood metabolite profiles and performance of transition cows. J. Anim. Feed Sci., 17: $473-490$

Sutton J.D., Phipps R.H., B e ever D.E., Humphries D.J., Hartnel1 G.F., Vic in i J.L., H a r d D.L. (2003). Effect of method of application of a fibrolytic enzyme product on digestive processes and milk production in Holstein-Friesian cows. J. Dairy Sci., 86: 546-556.

V i c in i J.L., B a te m a n H.G., B hat M.K., C lark J.H., Erdman R.A., Ph i p p s R.H., V a n A mburgh M.E., Hartne 11 G.F., Hint z R.L., H a rd D.L. (2003). Effect of feeding supplemental fibrolytic enzymes or soluble sugars with malic acid on milk production. J. Dairy Sci., 86: $76-585$

Wang Z., Eastridge M.L., Qiu X. (2001). Effects of forage neutral detergent fiber and yeast culture on performance of cows during early lactation. J. Dairy Sci., 84: 204-212.

W o h lt J.E., C o r c i o n e T.T., Z a j a c P.K. (1998). Effect of yeast on feed intake and performance of cows fed diets based on corn silage during early lactation. J. Dairy Sci., 81: 1345-1352.

Y ang W.Z., B e a u c h e m in K.A., R o d e L.M. (1999). Effect of an enzyme feed additive on extent of digestion and milk production of lactating dairy cows. J. Dairy Sci., 82: 391-403.

Accepted for printing 18 VII 2011

\section{MAGDALENA ŁOPUSZAŃSKA-RUSEK, KRZYSZTOF BILIK}

\section{Wpływ dodatku enzymów fibrolitycznych, żywych kultur drożdżowych lub obu preparatów razem przed i po porodzie na wydajność i profil metaboliczny krów mlecznych}

\section{STRESZCZENIE}

Celem badań było określenie, w jakim stopniu żywienie krów mlecznych w okresie okołoporodowym dawkami kompletnymi (TMR) z dodatkiem enzymów fibrolitycznych i/lub żywych kultur drożdżowych wpłynie na pobranie i wykorzystanie paszy, wydajność i skład chemiczny mleka oraz wskaźniki metaboliczne i rozrodcze krów. Doświadczenie przeprowadzono w okresie od 3. tygodnia przed wycieleniem do 10. tygodnia laktacji na 36 krowach rasy PHF odmiany czerwono-białej, przydzielonych do czterech analogicznych grup (po 9 sztuk). Krowy z grupy kontrolnej (C) otrzymywały dawkę bez badanych dodatków, z grupy doświadczalnej E dawkę z dodatkiem (15 g/dzień) preparatu enzymatycznego FibrozymeTM, zawierającego kompozycję aktywnej ksylanazy i celulazy, z grupy D dawkę z dodatkiem (10 g/dzień) preparatu drożdżowego Yea - Sacc1026, zawierającego żywą kulturę drożdży szczepu Saccharomyces cerevisiae1026, a z grupy ED dawkę z dodatkiem (25 g/dzień) mieszaniny obu dodatków paszowych. Preparaty dodawano do mieszanki treściwej wchodzącej w skład dawki kompletnej (TMR). Stwierdzono, że w grupach E i D zarysowała się tendencja do wyższego niż w grupie K pobrania suchej masy i składników pokarmowych. W grupach E, D i ED odnotowano również tendencję do uzyskiwania wyższej (o około 4-12\%) wydajności mlecznej w pierwszych trzech tygodniach laktacji oraz nieco większej w okresie 10-tygodniowej laktacji (odpowiednio o 0,16; 0,09 i 0,04 jednostek procentowych) zawartości białka ogólnego, bez wyraźnego wpływu na pozostałe składniki mleka. W grupie E zanotowano również istotnie niższą zawartość mocznika $(\mathrm{P}<0,05) \mathrm{w}$ mleku w porównaniu z grupą K. Krowy z grup E i D charakteryzowały się również lepszym w porównaniu z grupą 
$\mathrm{K}(\mathrm{P}<0,05)$ wykorzystaniem paszy i składników pokarmowych na produkcję $1 \mathrm{~kg}$ mleka, zwłaszcza w pierwszych trzech tygodniach po wycieleniu. U krów doświadczalnych wykazano także tendencję do poprawy profilu metabolicznego krwi, zwłaszcza zmniejszenia poziomu kwasu $\beta$-hydroksymasłowego (BHBA) i obniżenia aktywności aminotransferazy asparaginowej (AST). Nie stwierdzono istotnego wpływu badanych preparatów na masę i kondycję ciała krów ani na wskaźniki rozrodu. 